\title{
David Pollard, The True Story of Lu Xun
}

Hong Kong, The Chinese University Press, 2002, 242 p.

\section{Sebastian Veg}

\section{OpenEdition}

\section{Journals}

Édition électronique

URL : http://journals.openedition.org/chinaperspectives/794

DOI : 10.4000/chinaperspectives.794

ISSN : 1996-4617

Éditeur

Centre d'étude français sur la Chine contemporaine

Édition imprimée

Date de publication : 1 février 2004

ISSN : 2070-3449

\section{Référence électronique}

Sebastian Veg, "David Pollard, The True Story of Lu Xun », China Perspectives [En ligne], 51 | januaryfebruary 2004, mis en ligne le 23 avril 2007, consulté le 21 septembre 2020. URL : http://

journals.openedition.org/chinaperspectives/794 ; DOI : https://doi.org/10.4000/chinaperspectives 794

Ce document a été généré automatiquement le 21 septembre 2020

(c) All rights reserved 


\section{David Pollard, The True Story of Lu Xun}

Hong Kong, The Chinese University Press, 2002, 242 p.

\section{Sebastian Veg}

\section{NOTE DE L'ÉDITEUR}

Translated from the French original by Philip Liddell

1 David Pollard's book, the first reliable biography of Lu Xun in a Western language, fulfils a real need, so closely is the subject's life linked with the great events of the first third of the twentieth century in China. Aimed at the uninformed reader, the biography is written in a pleasant style, free of notes and detailed references to ideological or literary issues in which $\mathrm{Lu}$ Xun was involved. It presents a balanced synthesis of Chinese sources, such as Lu Xun's diary and the memoirs published about him (by his brothers Zhou Zuoren and Zhou Jianren, by his wife Xu Guangping, and by his friends), or of more recent research into various episodes of his life. It includes a chronology of his life and suggestions on further reading, but there is no index or formal bibliography.

2 Three episodes deserve mentioning for the new information they may represent for Western scholars of Lu Xun. At the purely private level, Pollard gives us a valuable insight into Lu Xun's arranged marriage in 1906 to Zhu An, an illiterate woman from Shaoxing with bound feet. Like Hu Shi and Yu Dafu, Lu Xun agreed to submit to a marriage of this kind but went on later to live with his student Xu Guangping. David Pollard concludes that Lu Xun's mental worlds were distinctly separated (which may throw light on some of his stories): on the one hand, the traditional world of filial piety and on the other, the modern world of free marriage. These worlds coexist but never overlap.

3 Pollard goes on to tackle the 1923 break between Lu and his brother Zhou Zuoren. The two brothers, very close until the early 1920s, as both were leading representatives of 
the New Culture Movement and fellow-teachers at Peking University, but they never saw each other or wrote to each other again after their quarrel. Pollard conjectures that there had been an ambiguous relationship between Lu and Habuto Nobuko, Zhou's Japanese wife, whom Lu had known before his brother when he was studying in Japan ${ }^{1}$. Lastly, in a less affective vein, the book narrates the encounter between $\mathrm{Lu}$ and the historian $\mathrm{Gu}$ Jiegang, another leading intellectual of the republican period, at Xiamen University in 1927, at a time when both were fugitives from the anticommunist persecutions of the warlord Zhang Zuolin in Peking. Pollard shows how Gu Jiegang attempted to win Lu's favour by offering him copies of his books and how Lu, refusing any comment on the innovative theories that Gu was developing on Chinese history, took pleasure in mocking him as a henchman of Hu Shi and ridiculing his stammering and his red nose.

5 These three episodes illustrate both the qualities and the defects of the book. It is a highly approachable biography, but lacks ambition in analysing Lu's intellectual development. We may cite here the example of the conservative revolutionary Zhang Binglin (1868-1936) whom Pollard mentions only briefly and who exercised an undeniable influence on Lu Xun. After Zhang's death, Lu was to devote two texts to him, written a few days before his own death. While he had always rejected, sometimes vehemently, the "national essence" theories that Zhang had developed, Lu explained in these two texts that he remained loyal to Zhang, the Confucian man of letters turned revolutionary polemicist, and that he would like his polemical writings to be republished. Here also is to be found a key to understanding the poem "Original inscription on a little photograph" (Ziti xiaoxiang), which Lu had written in Tokyo in 1903 on the back of a photo of himself taken after he had cut off his braid. Pollard reads this poem in a purely anecdotic way, decoding it as a veiled allusion to the marriage that Lu's mother was arranging between him and Zhu An. But the last line ("I shall give my life for the Emperor Xuanyuan", otherwise known as the Yellow Emperor, the mythical ancestor of the Han race) brings Lu close to the theories of Zhang Binglin, whose classes he had not yet attended at this time, but who had written in 1901 an article describing how he had cut off his own braid, mentioned by Lu in the homage to his master.

6 Lu Xun's thinking lends itself only too well to a narrative placing the main emphasis on personal connections, as Pollard shows by drawing up a list of men who, like him, were from Zhejiang and to whom he was close. One example is Cai Yuanpei, his mentor at Peking University, who allowed him as Director of the Daxue Yuan (the Higher Education Minister) in the Chiang Kai-shek government, to draw an annual income of 300 yuan from January 1928 to December 1931, during which period he was moving closer to the Communist Party. Thus, all Lu's intellectual commitments seem to result from personal connections forged with men and women from Zhejiang, taking him from the nationalism of the revolutionary Qiu Jin (executed in 1907) and of Zhang Binglin, by way of Qian Xuantong (who drew him into the May $4^{\text {th }} 1919$ Movement) and $\mathrm{Xu}$ Shouchang (who obtained for him a teaching post in the Peking University), to the Marxism of the "revolutionary martyr" Rou Shi (executed in 1931) and of Feng Xuefeng (the friend of his last years). Lu's loyalty to his own native town and to his origins ought to have been examined as a puzzling element in his personality and intellectual evolution. We should have liked to know more about Lu's relationship with Hu Shi, to whom he had not always shown such deep hostility as he did during the 1930s, with the 
writer Yu Dafu, who he befriended in Shanghai despite their political and aesthetic differences, and particularly with Chen Duxiu ${ }^{2}$ with whom he shared part of the intellectual journey that was to lead Chen towards Trotskyism and Lu towards the leftist protests in 1936 against the united front policy dictated by Moscow.

\section{NOTES}

1. David Pollard has published a book on Zhou Zuoren, A Chinese Look at Literature: The Literary Values of Zhou Zuoren in Relation to the Tradition, London, Hurst, 1973. 2. On this subject, the reader may consult Lu Xun's essay, "To the Memory of Liu Bannong", written in August 1934, which paints rather an ambiguous picture of his relations with Chen Duxiu and Hu Shi at the time of the May $4^{\text {th }}$ Movement. Wang Hui has devoted several studies, based on Lu's early writings, to the ambiguous relationship between Lu and the "leading lights" of the May $4^{\text {th }}$ Movement, notably the first part of his book Fangkang Juewang (Resist Despair), Shijiazhuang, Hebei jiaoyu chubanshe, $20002^{\text {nd }}$ edition (collection "Regards rétrospectifs sur Lu Xun"), entitled "Les antithèses de la pensée: individu et nation, progrès et cyclicité". In Chinese: collection "Hui wang Lu Xun", chapter title: Sixiang de beilun: geren yu minzu, jinhua yu lunhui”. 